\title{
RURAL ARCHITECTURAL HERITAGE CONSERVATION AND SUSTAINABILITY IN TURKEY: THE CASE OF KARACA VILLAGE OF MALATYA REGION
}

\author{
TUBA NUR OLĞUN \& MÜJGAN BAHTIYAR KARATOSUN \\ Architecture Faculty, Fırat University, Turkey \& Architecture Faculty, Dokuz Eylül University, Turkey.
}

\begin{abstract}
The rural architectural heritage has become a field of study in which many studies have been carried out and the importance of which has been recognized in the world in recent years. The rural areas, which are unique in their physical and social sense with their unique characteristics, are unique in their architectural terms. In this context, conserving the architectural heritage in rural areas and making these areas sustainable have great importance.

Rural architectural heritage conservation is an issue discussed in Turkey as in many countries around the world. However, the developments seen in this area in Turkey, considered a fairly new compared with developments in the world. Thus, when looking at studies in Turkey, for the conservation of the rural architectural heritage, it is seen that there are many studies in literature and practice in some rural areas. But, there are no studies on that heritage in some areas.

There are many parameters that characterize the rural architectural heritage. One of these parameters is the building material. Considering the rural architectural heritage in Turkey, especially building materials according to geography and climate conditions, it is observed that the shape of use. In this context, natural materials such as stone, wood and earthen are common in rural areas. In particular, the earthen material used by conventional techniques is not long lasting; the widespread use of these materials causes rapid destruction of architectural elements. In this sense, it has great importance to accelerate the efforts for the conservation of the architectural heritage built with earthen material and to implement the practices as soon as possible.

In Turkey, one of four in rural architectural heritage built with earthen material located in the most intense region is Malatya. Karaca Village, which is located in the east of the Malatya, is a very striking example with its qualities. However, there are no studies on this and many other examples. In this context, the aim of the study; in Turkey, especially earthen material should attract attention to rural architectural heritage and to contribute to the preservation of this heritage. In the study, as first, the conservation of the rural architectural heritage in the world and Turkey and will be examined for the sustainability process; then, the rapidly losing areas of earthen material will be emphasized. Thus, in this sense stands out in Turkey, Malatya, located in the village of Karaca will be elaborated. As a result of the study, both in the world, in both Turkey; to discuss the current status of the rural architectural heritage built with earthen material; it is aimed to contribute to the preservation and sustainability of this heritage.
\end{abstract}

Keywords: conservation, Malatya, rural architecture heritage, sustainability, earthen.

\section{INTRODUCTION}

Conservation and sustainability are two basic concepts frequently discussed in the architectural discipline. These concepts, which are in close relationship with each other, come to the agenda, especially in matters related to architectural heritage. In this context, the studies on the conservation and sustainability of the architectural heritage are being developed and increasing.

The development of conservation thought in architecture can be carried out until the beginning of the art of building. However, there are differences between the conservation concept of the past and the present. In the past, only religious, national or ideological symbols and generally acclaimed structures have been conserved. Today, however, the scope of 
conservation has exceeded the single building scale and the modest structures which constitute a historical settlement are conserved. In this sense, a historical street, city, neighborhood or village is adopted as a value to be conserved. [1].

When the relationship between sustainability and architecture is examined, it is seen that the studies in this area have started to develop in the near future. Sustainability has been adopted as a guide for many disciplines [2]. Sustainability, whose sources are balance, responsibility, planning, participation, scientific efficiency, communication, integration and equality, are closely related to architecture [3]. Therefore, the framework of sustainable design in architecture can be expressed as in Fig. 1.

There are some criteria for a structure or settlement to be worth conserving and carry sustainable qualities. These criteria are; historical document quality, antiquity and aesthetic value. Structures and settlements having one or more of these criteria are worth conserving [1]. In this context, it can be stated that rural areas which have a long-standing history are worth conserved and sustainable in the framework of these criteria. The aim of this study to move here is to draw attention to the rural architectural heritage in Turkey and in particular to contribute to the conservation and sustainability of this heritage. Within the scope of the study, the process of conservation and sustainability of the rural architectural heritage of which the importance of which is understood recently has been examined. In this heritage, the surveys will be conducted on the rapidly lost earthen material areas. In the world and in Turkey in the process of advancing the conservation of the rural architectural heritage in the context of different periods, Karaca village located in Malatya which is in this sense stands out in Turkey will be discussed. As a result, with the study, it is aimed to discuss the current status of rural architectural heritage; however to contribute to the conservation and sustainability of the said heritage.

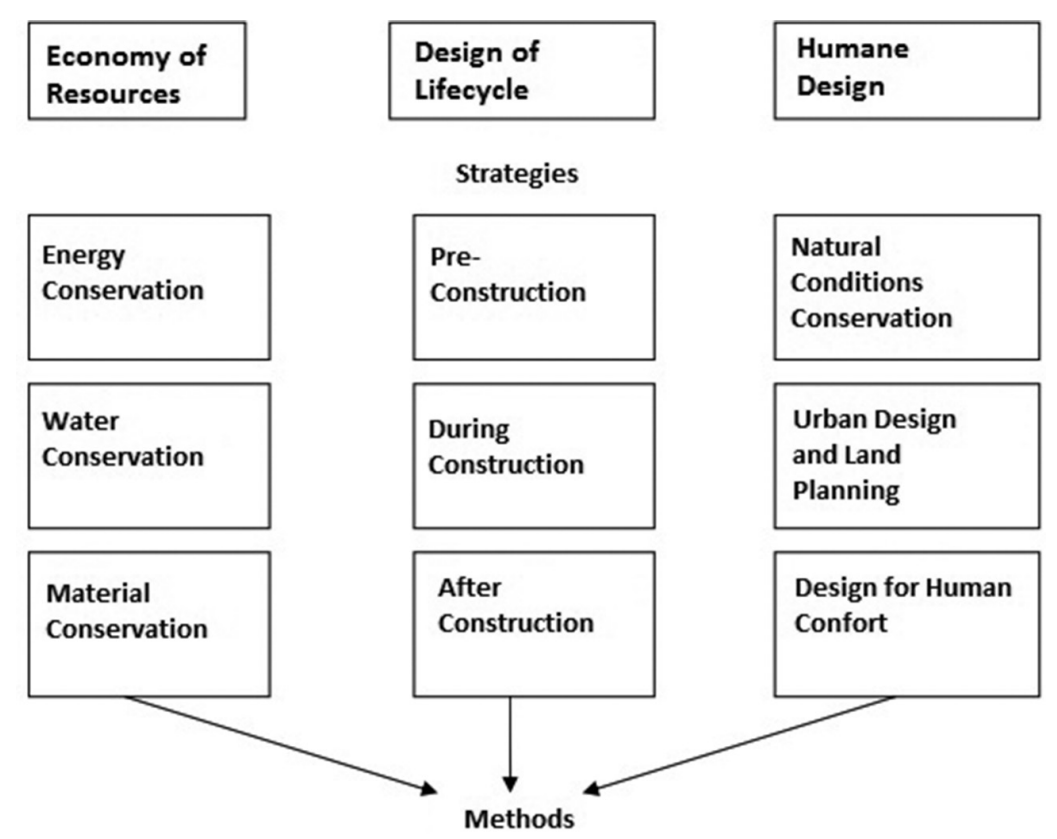

Figure 1: Framework for sustainable design [2, 4]. 


\section{STUDIES ON CONSERVATION AND SUSTAINABILITY OF RURAL ARCHITECTURAL HERITAGE}

Rural architectural heritage is a value that its importance is increasing in the context of conservation in recent years. Settlements generally referred to as villages have sustainable qualifications with;

- Traditional buildings (house, warehouse, workshop, barn, etc.)

- Special areas such as gardens and courtyards that are designed with those traditional buildings,

- Public open spaces such as village square, cemetery and pasture. [5].

While the rural settlements, which are worth protecting with these qualities, are considered, the parameters that are distinctive in the evaluation of these settlements can be listed as follows:

- Containing elements that need to be protected and with the influence of nature and the human hand,

- Homogeneous and uniform distribution of these elements in the settlement,

- Having not lost its natural and local characteristics due to contemporary uses,

- Maintaining traditional production techniques,

- Existing building stock's carriage of traditional values and qualities specific to the region.

When we look at the development of studies on the conservation of rural architectural heritage, the first step taken in this area is the first item under the heading 'Definitions', in the Venice Charter of 1964. The item is 'The concept of a historic monument embraces not only the single architectural work but also the urban or rural setting in which is found the evidence of a particular civilization, asignificant development or a historic event. This applies not only to great works of art but also to more modest works of the past which have acquired cultural significance with the passing of time'. The most important statements after this work are included in the 1975 Declaration of Amsterdam. The phrases are in the declaration have a big importance that 'The architectural heritage includes not only individual buildings of exceptional quality and their surroundings, but also all areas of towns or villages of historic or cultural interest' [6].

The Valetta Principles for the Protection and Management of Historic Cities and Urban Areas developed in 2011 can be considered as one of the most comprehensive studies in the context of conservation of rural architectural heritage. In this sense, there are phrases under the title of 'Historic towns and urban areas' that:

'Historic towns and urban areas are made up of tangible and intangible elements. The tangible elements include, in addition to the urban structure, architectural elements, the landscapes within and around the town, archaeological remains, panoramas, skylines, viewlines and landmark sites. Intangible elements include activities, symbolic and historic functions, cultural practices, traditions, memories, and cultural references that constitute the substance of their historic value.

Historic towns and urban areas are spatial structures that express the evolution of a society and of its cultural identity. They are an integral part of a broader natural or man-made context and the two must be considered inseparable.

Historic towns and urban areas are living evidence of the past that formed them. 

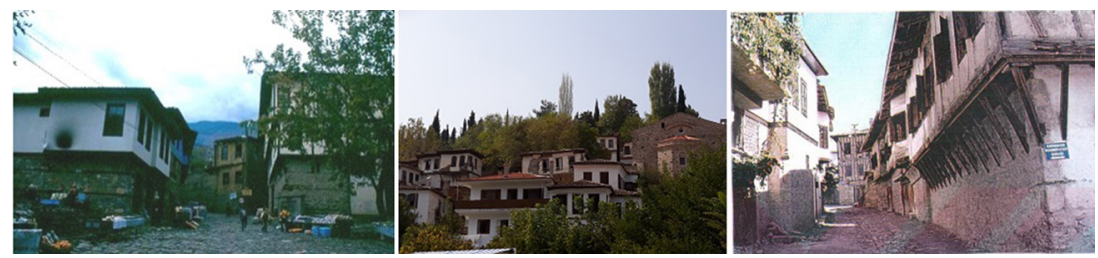

Figure 2: Traditional Cumalıkızık, Şirince and Yörük villages in Turkey [7, 8].

Historical or traditional areas form part of Daily human life. Their protection and integration into contemporary society are the basis for town-planning and land development.'

There are some phrases in the same principles' title of 'Change and the natural environment' that:

'In historic towns and urban areas, change should be based on respect for natural balance, avoiding the destruction of natural resources, waste of energy and disruption in the balance of natural cycles.

Change must be used to: improve the environmental context in historic towns and urban areas; improve the quality of air, water and soil; foster the spread and accessibility of green spaces; and to avoid undue pressure on natural resources.

Historic towns and their settings must be protected from the effects of climate change and from increasingly frequent natural disasters.

Climate change can have devastating consequences for historic towns and urban areas because, in addition to the fragility of the urban fabric, many buildings are becoming obsolete, requiring high levels of expenditure to tackle problems arising from climate change.

The aim should be to take advantage of strategies arising from growing global awareness of climate change and to apply them appropriately to the challenges of safeguarding historic towns.' [6].

Studies for conserve the rural architectural heritage in Turkey can be evaluated fairly new. The lack of any legal work in this area for many years has caused the extinction or neglect of many qualified rural architectural heritage in the country. Today, although there are no expressions on the conservation of the rural architectural heritage within the legal regulations about conservation, it is possible to mention various applications. The studies performed in settlements such as Cumalıkızık, Şirince and Yörük are some of these applications (Fig. 2). However, issued in 2013 by the ICOMOS Turkey Architectural Heritage Conservation Charter 'rural sites' definition was made in the following way: 'The layout, construction technique and design of the structures that are the product of the local; road, square, agricultural area etc. by combining with the elements; they are rural areas with values to be conserved.' [6]. Hence, it can be stated that the studies that conservation and sustainability of the rural architectural heritage in Turkey are not enough; there are almost no information and documents about many valuable areas.

\section{KARACA VILLAGE OF MALATYA REGION IN THE CONTEXT OF CONSERVATION AND SUSTAINABILITY}

Anatolia is located in the territory of Turkey that has a rich settlement which has hosted various civilizations. This wealth has led to the emergence of a wide variety of architectures in different parts of Anatolia. Especially geographical data (climate, vegetation, slope, etc.) and socio-cultural characteristics determined the characteristics of Anatolian architecture. In this context, one of the settlements in Anatolia is Malatya. 
Located in the west of the Eastern Anatolia Region, Malatya; has rich resources and nonharsh climatic conditions due to its geographical location; is a developed Anatolian city [9] (Fig. 3).

At an intersection of historical roads since ancient times; Malatya, which has a strategic importance, has been under the influence of many civilizations thanks to this feature. Some of these civilizations can be listed as Assyrians, Persians, Hittites, Hellenic and Roman Empires, Ilkhanians, Eretnas, Mamluks, Seljuk and Ottoman Empires [11, 12, 13, 14].

Today, Malatya, which is a city that develops rapidly with migration, is also very rich in terms of rural settlements. In this sense, there are 13 districts connected to Malatya and hundreds of village settlements connected to these districts [15]. When the architectural characteristics of these villages are examined, it is seen that the main building material is stone in the village settlements on the hilly terrain. In the village settlements on the flat land, the main building material is mainly earthen. In addition to this, there are houses suitable for the living culture of the region and structures for livelihoods as well.

Some of the village settlements in the Malatya region retain their architectural characteristics; some have changed. The researches have shown the following:

- No architectural data (map, building characteristics, in-village transportation axis characteristics, etc.) were found in the official authorities regarding the villages with local characteristics.

- There is no study on conserving the architectural characteristics of villages in local regulations and practices.

- Depending on the economic situation, it is determined that the local people tend to demolish / abandon the traditional houses and build new concrete houses.

It can be stated that the situations listed above cause change.

One of the village settlements in Malatya, which stands out with its local characteristics in terms of its architectural characteristics, is the Karaca village (Figs. 4 and 5). Karaca village, which is a settlement of Yazihan district, has the following general characteristics:

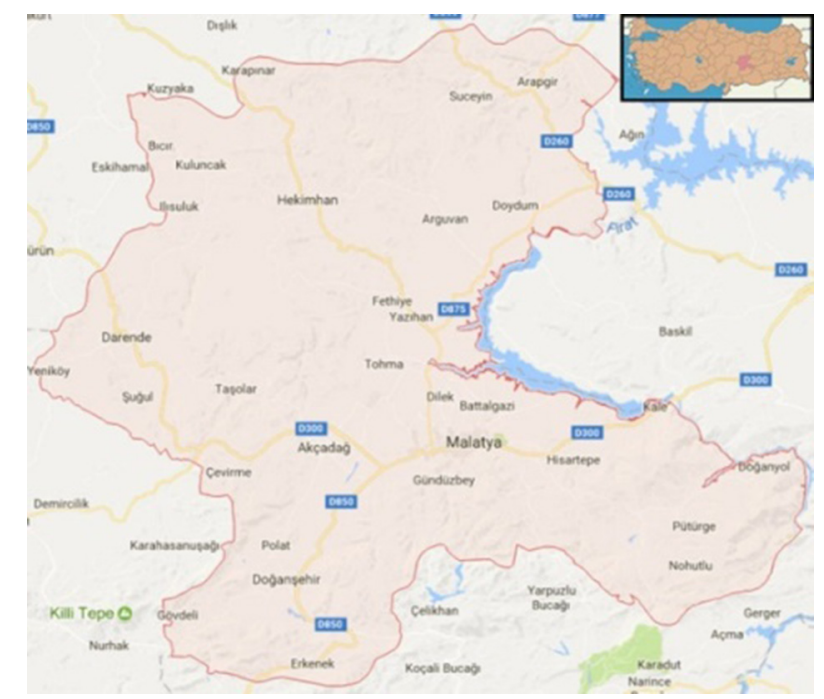

Figure 3: Location of Malatya [10, 11]. 


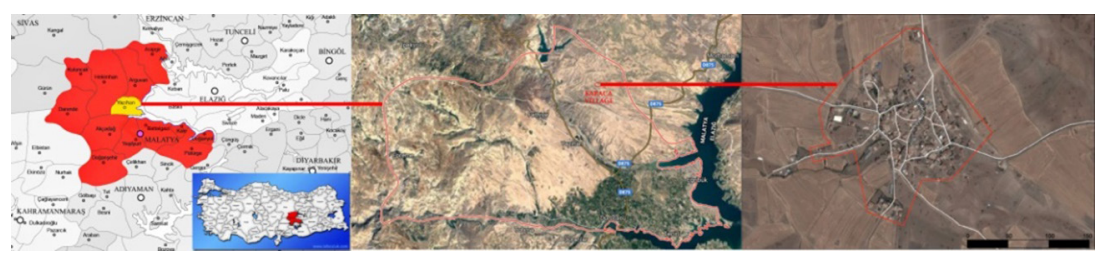

Figure 4: Location of Karaca Village [11].

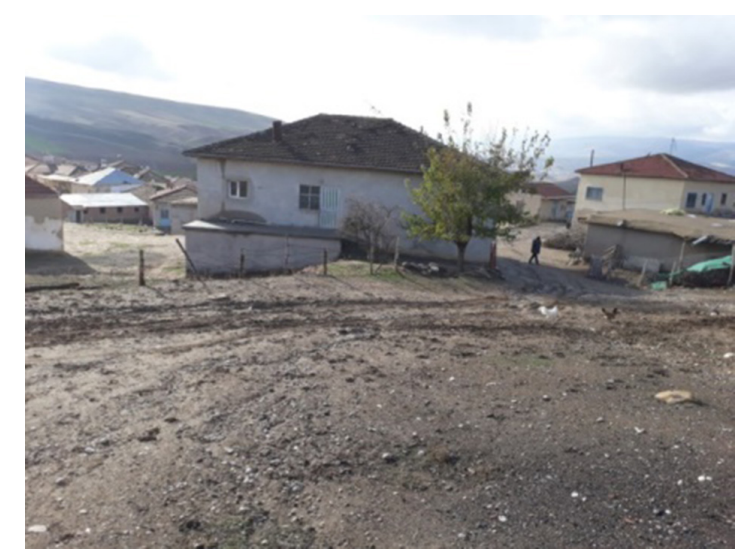

Figure 5: A view from Karaca Village.

Year / Population: 2017 / 229 (Male:110, Female:119)

$2016 / 244$

$2015 / 264$

2014 / 287

2013 / 248 [16].

Main livelihood: Livestock.

Public buildings in the village: Primary school, high school (inactive), cultural center, PTT (post, phone, telegraph) building (inactive), health center (inactive).

Historical data: 'The information about the history of Karaca is based on the village elders and the Ottoman books written before them. The founders of the village are from the tribe of Mr. Karacalı, son of Mr. Feyruz, who founded the state of Dulkadiroğulları from the Beydilli Turkmen tribe that came from Yıldız Han, the son of Oğuz Han of the Oğuz Turks, Bozok branch (Karacaalu). The village was founded in 1520. According to the rumors, during the great migration, they settled in the Maras region of Anatolia under the administration of the tribe and tribe of Horasan. Later, upon the disintegration of the Great Seljuks, Dulkadiroğulları came under the rule of the principality. Upon the collapse of the state by Yavuz Sultan Selim, the tribe of the governor Mr. Feyruz, $5 \mathrm{~km}$ north of today's Yazıhan district subcontinent, settled in the Çimisören location. A boy of Mr. Feyruz was born and named after Mr. Karaca. They lived in the plain for half a century and migrated to the present village.

According to rumors, the village's name comes from Mr. Karaca. In these settlements, they lived on livestock as they did before. They lived nomadic life between Yama Mountain and Ayranc1 Highlands and their mansions. They find their place insufficient for their lives; then they settled $6 \mathrm{~km}$ west of Çimisören location. Here they also engaged in farming; however, they provided their main livelihood by dealing with livestock. In here, Mr. Feyruz, the tribe chief, has 
passed away; the administration of the tribe took the hands of his son Mr. Karaca. Due to the fact that the land settled in time did not support the cave, they have come to the village (present location) which has a larger plantation area and constitutes the center within this field. Later, the village was named Karacalu, with respect to the names of its tribe and founders. In time, this name came to what was said as Karaca and thus entered the administrative records.' [17].

Planning and architectural data: Maps and architectural resources related to the village could not be reached. For this reason, the site plan of the settlement has been formed with the help of the studies carried out in the field (Fig. 6). There are approximately 140 buildings with different functions within the boundaries of the settlement area. It was found that 122 of these buildings were built with mudbrick materials and traditional construction techniques.

When the features of the settlement texture are examined, the following are seen:

- The settlement is composed of living areas in focus and agricultural areas surrounding these areas. In addition, not used for agricultural purposes; unregulated areas also surround the living areas of the village settlement.

- It is seen that the street pattern is shaped in an organic way.

- Most of the roads in the settlement are unregulated soil roads. Some roads are arranged with cobblestone (Fig. 7).

- Some houses within the settlement are designed to be adjacent to animal shelters. In some houses, animal shelters are arranged on the ground floor of living spaces (Fig. 8).

- Some of the houses are in the garden; most of them take direct entry from the street (Fig. 9).

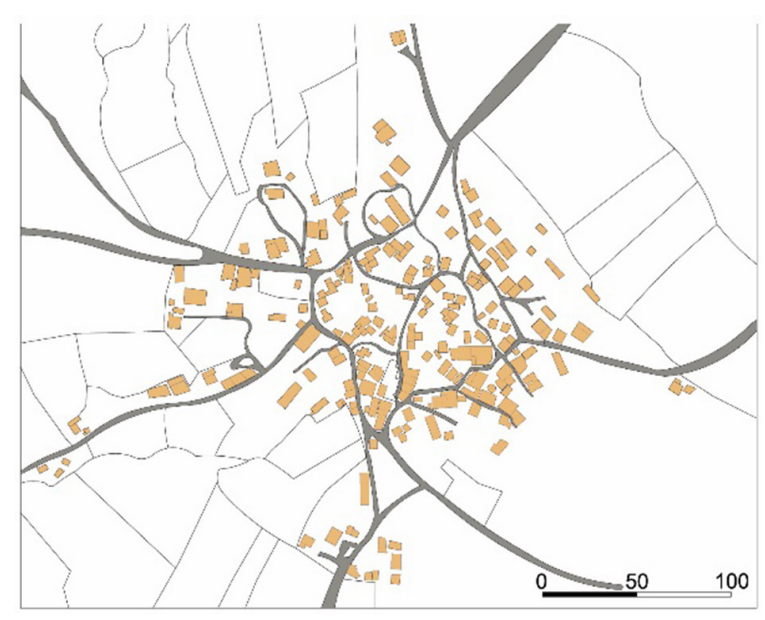

Figure 6: Site plan of Karaca Village.

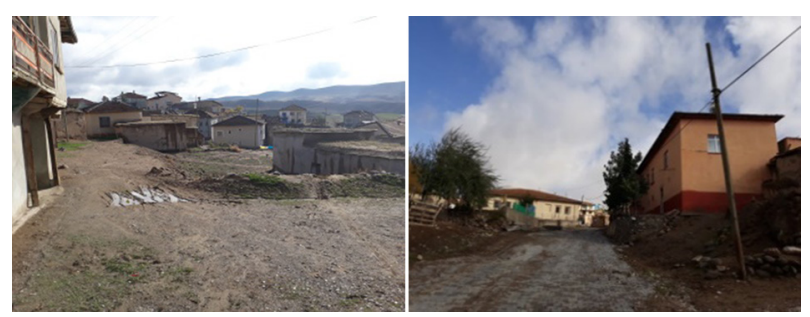

Figure 7: An earthen and a cobblestone ways. 


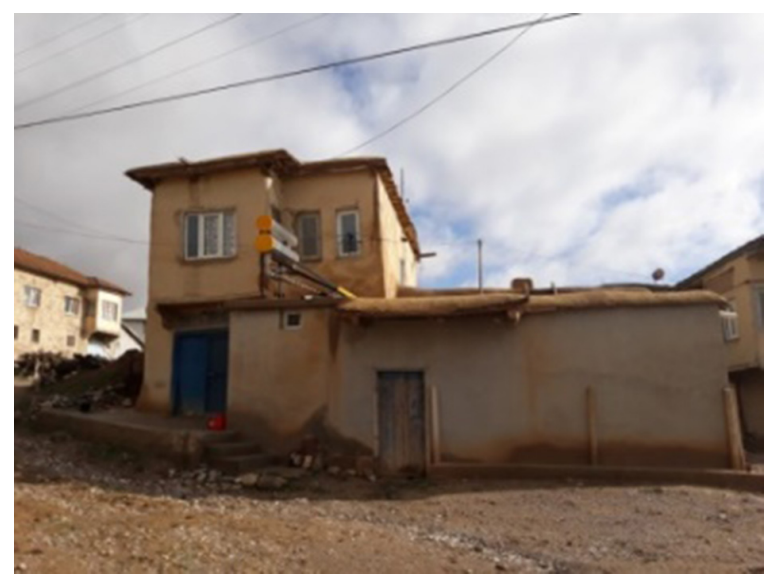

Figure 8: A house with an animal shelter.

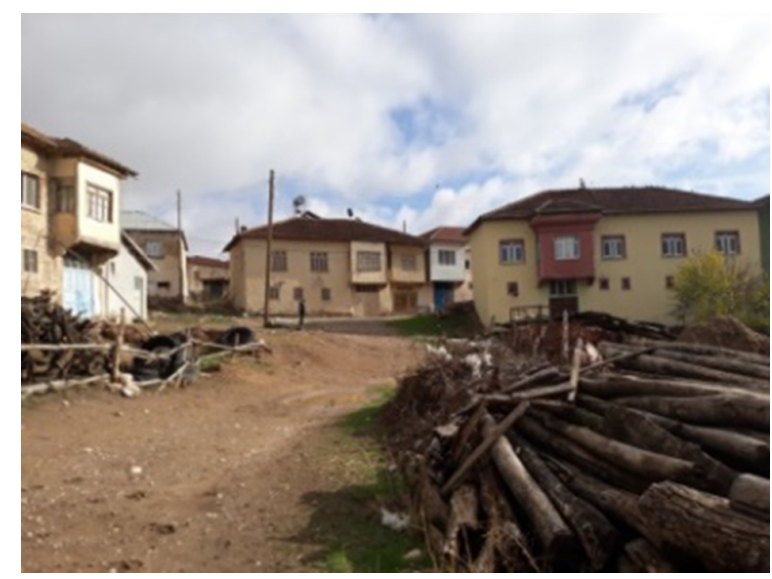

Figure 9: Buildings entered from the street.

- Structures are usually composed of one or two floors. Some of the two-storey buildings have exits on the entrance facades. However, in some buildings, the outer surfaces of the windows are arranged as windows that are specific to the region, called the "window with kantamar' (Fig. 10).

- Some of the buildings constructed with mudbrick material were plastered with concrete material in order to increase the life of the building.

Social data: As a result of on-site investigations, it was found that a large part of the village inhabitants lived in the cities; they preferred to be in the village at certain times of the year. Most of the residents of the villages are from the profession groups such as teacher, lawyer, doctor, engineering, architecture and military service. In this way, most of the residents of the cities continue to use their mudbrick structures by repairing them. Some have preserved mudbrick structures, but have added reinforced concrete inserts. 


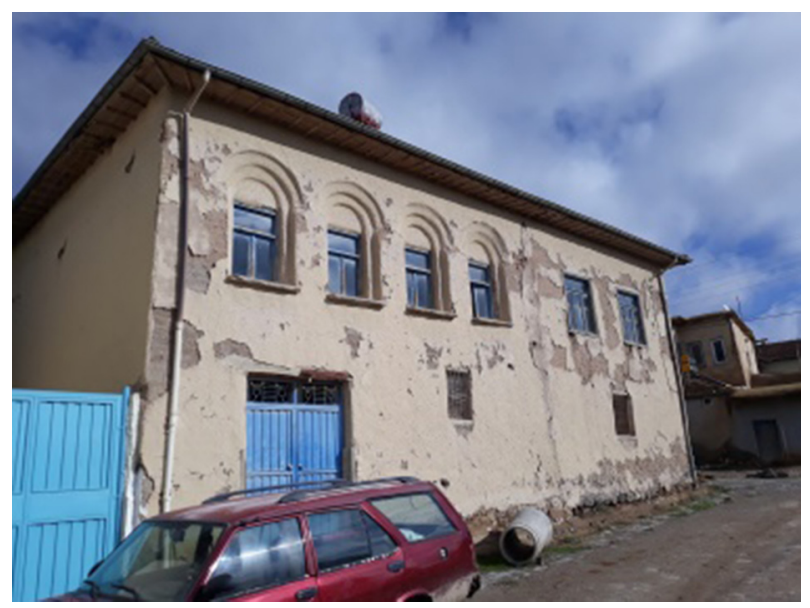

Figure 10: An example of window with 'kantamar'.

\section{Conservation Problems:}

- There is no documentation about the original texture of the area and the structures that make up this texture. This paves the way for the destruction of many original structures before they can be documented.

- Reinforced concrete parts added to houses negatively affect the original characteristics of these buildings.

- In order to protect the buildings from harmful external influences, their facades are plastered with concrete. Therefore, the original facade characteristics of many buildings disappear.

- Some of the original structures in the settlement were built as reinforced concrete. This situation undermines the general characteristics of the settlement (Fig. 11).

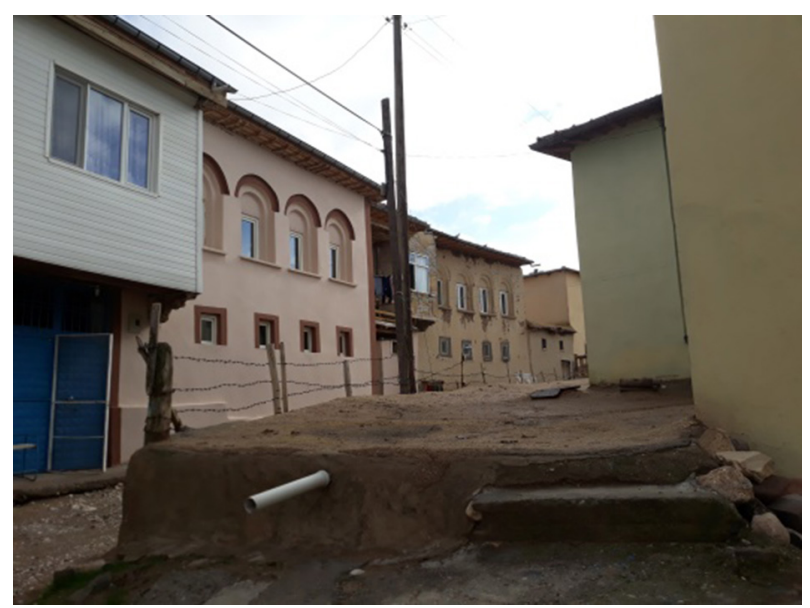

Figure 11: An example of window with 'kantamar'. 
- The number of roads arranged in the settlement is quite small.

- Assistance was requested from various institutions for the maintenance and repair of mudbrick structures in the village; but no return. The authorities ignore the qualities of the settlement that are worth conserving.

\section{EVALUATION AND CONCLUSIONS}

Rural architectural heritage has become a phenomenon in which many studies and applications have been carried out especially in recent years. When the developments in this sense in the world are examined, it is seen that the said heritage is protected by legal regulations; there is no study on this subject in Turkey. Therefore, the nature of the rural architectural heritage with many settlements in Turkey, undergoes radical changes or is completely lost before it can be registered.

Featured on rural architectural heritage and deep-rooted respect, Turkey Anatolian city of Malatya, are known to be particularly dense with buildings of earthen and villages with indigenous characteristics space. However, many of these villages are not included in the literatüre and there are no studies to conserve these villages as rural architectural heritage. In this context, the rural architectural heritage in the Malatya region is undergoing many changes.

Located in the Malatya region, Karaca village is a settlement with unique architectural characteristics that can be described as rural architectural heritage. From this point of view, evaluations regarding the settlement can be made as follows:

\section{Karaca Village as a Rural Settlement Worth Conserving:}

- Consisting of human hands; contains elements that need to be protected. One of these elements is earthen structures with original architectural characteristics.

- These elements are distributed homogeneously and harmoniously within the settlement.

- It has not lost its natural and regional qualities due to contemporary uses. But; no conservation work is carried out to transfer these qualities to future generations.

- Each household in the settlement continues to produce the fruits, vegetables and animal sourced foods that they need by using traditional techniques.

- The existing building stock has traditional values and qualities specific to the region.

\section{Karaca Village In the Context of Sustainable Architectural Design:}

- In the context of conservation of resources, it can be stated that the material and energy are conserved due to the use of local earthen materials in buildings.

- With the use of traditional materials and construction techniques; In addition, the life cycle of the settlement is designed to be sustainable by arranging spaces suitable for the culture of living.

- Natural conditions have been preserved and structures suitable for the comfort of the local people have been designed. Thus, a settlement area was created where humanitarian design became prominent.

As a result, architectural heritage is a universal concept. In this context, the architectural heritage in Turkey is also valuable to the whole world. Hence, although Turkey has an important potential in terms of the rural architectural heritage, the application for the conservation of this heritage is quite insufficient. In this sense, it is thought that this study, through Malatya 
region's Karaca village, will contribute to an increase in regulations and practices for the conservation of the rural architectural heritage in Turkey.

\section{REFERENCES}

[1] Ahunbay, Z., Tarihi Çevre Koruma ve Restorasyon, YEM Publication: İstanbul, pp. 8-27, 1999.

[2] Ciravoğlu, A., Sürdürülebilirlik Düşüncesi-Mimarlık Etkileşimine Alternatif Bir Bakış: "Yer" in Çevre Bilincine Etkisi", Y1ld1z Technical University, The Graduate School of Natural and Applied Sciences, PhD Thesis: İstanbul, pp. 118-119, 2006.

[3] Gallager, A., Developing a standard for sustainability appraisal in coastal management, Proceedings of the Sixth International Conference on the Meditterranean Coastal Environment, pp. 133-144, 2003.

[4] Bekişoğlu, Ü., Safranbolu Yörük Köyü Tarihi Çevresinin Peyzaj Planlaması, Ankara University, The Graduate School of Natural and Applied Sciences, Master Thesis: Ankara, pp. 54-55, 2002.

[5] Madran, E. \& Özgönül, N., Kültürel ve Doğal Değerlerin Korunması, TMMOB Chamber of Architects of Turkey: Ankara, pp. 48-57, 2005.

[6] Charters, ICOMOS, Online, http://www.icomos.org.tr/?Sayfa=Tuzukler2\&dil=tr, (accessed 04 May 2019).

[7] Perker, S.Z. \& Akıncıtürk, N., Cumalıkızık'da ahşap yapı elemanı bozulmaları. Uludă̆ University Journal of Engineering-Architecture Faculty, 11(2), pp. 43-51, 2006.

[8] Kim, J. \& Ridgon, B., Introduction to Sustainable Design, National Pollution Prevension Center for Higher Education: Michigan, pp. 16-20, 1998.

[9] Demirbăg, H., Dört Mevsim Malatya, Malatya Provincial Directorate of Culture and Tourism, The library of Malatya Publication: Malatya, pp. 59-74, 2013.

[10] Bahtiyar Karatosun, M. \& Olğun, T.N., Evaluation of the material-protection sustainability relationship on the identity of traditional settlements. Proceedings of the Second Conservation of Architectural Heritage Conference, pp. 66-74, 2018.

[11] Malatya, Google Map, Online, https://www.google.com/maps/place/Malatya/@38.353 0218,38.2059173,12z/data=!3m1!4b1!4m5!3m4!1s0x407636e4923c4bad:0xa053ec48 de5f481b!8m2!3d38.3553627!4d38.3335247 (accessed 10 December 2017).

[12] Metin, T., Selçuklular Döneminde Malatya, Malatya Provincial Directorate of Culture and Tourism, The Library of Malatya Publication: Malatya, pp. 28-36, 2013.

[13] Ağaldağ, S., Malatya Eskiçağ Tarihi, Malatya Provincial Directorate of Culture and Tourism, The Library of Malatya Publication: Malatya, pp. 108-112, 2016.

[14] Zengin, M., İlhanlılar-Eretnalılar-Memlûklar Dönemi Malatya (1295-1401), Malatya Provincial Directorate of Culture and Tourism, The Library of Malatya Publication: Malatya, pp. 67-74, 2017.

[15] Malatya İlçeleri, Malatya Kültür A.Ş., http://www.malatyakultur.com/malatya-tanitim/ malatyanin-ilceleri (accessed 08 May 2019).

[16] Karaca Köyü Nüfus Verileri, TÜİK, http://www.tuik.gov.tr/Start.do, (accessed 06 December 2018).

[17] Karaca Tarihçesi, Kar-Der, Online, http://www.karder.org.tr/index.php/karaca-koyu/ karaca-tarihcesi/ (accessed 06 December 2018). 